\title{
AIR TEMPERATURE AND PRECIPITATION ON THE GREENLAND ICE SHEET
}

\author{
By Marvin Diamond* \\ (U.S. Army Signal Missile Support Agency, White Sands Missile Range, New Mexico, \\ U.S.A.)
}

\begin{abstract}
Mean annual air temperatures and precipitation on the Greenland Ice Sheet, as estimated from snow profile studies and long-term meteorological records at coastal stations, have been used to prepare mean annual air temperature and mean annual precipitation charts for the Greenland Ice Sheet. It is shown that melting of surface snow may occur at elevations of about 1,300 m. in north Greenland and up to 2,700 $\mathrm{m}$. in south Greenland. The warming trend in the Arctic, as indicated by increases in mean annual air temperature, may have occurred to a lesser extent on the ice sheet than at sea-level coastal stations. Annual accumulation of precipitation is two or three times as great at $2,700 \mathrm{~m}$. on the west side of the ice sheet as at the crest. South of lat. $66^{\circ} \mathrm{N}$., precipitation may be about twice as great on the east side of the crest as on the west side.

Résumé. Des études de profils de neige, et des séries d'observations météorologiques à long terme des stations côtières, ont permis de calculer les températures moyennes annuelles et les précipitations neigeuses sur l'inlandsis groenlandais: on a établé des tableaux et des cartes de ces évaluations. On a trouvé que la fonte de la neige superficielle peut se produire à des altitudes de $1300 \mathrm{~m}$ environ dans le nord du Groenland, et jusqu'à $2700 \mathrm{~m}$ dans le sud du pays. Le réchauffement générale dans l'ensemble de l'Arctique, confirmé par l'accroissement de la température moyenne annuelle de l'atmosphère, est pourtant peut-être moins marqué sur l'inlandsis que dans les stations côtières à niveau de la mer. L'alimentation annuelle due à la précipitation neigeuse à $2700 \mathrm{~m}$ est deux ou trois fois plus importante sur le versant occidental de l'inlandsis qu'elle ne l'est au sommet. Au sud de la ligne de latitude $66^{\circ} \mathrm{N}$ les précipitations sont deux fois plus considérables sur le versant à l'est du sommet qu'elles ne le sont sur le versant occidental.
\end{abstract}

Zusammenfassung. Auf Grund von Schneeprofile und von Küstenstationen gemachter vieljähriger meteorologischer Beobachtungen wurden geschätzte Jahresmittel der Lufttemperaturen und Niederschläge für das grönländische Inlandeis benutzt, um Jahresmittelkarten und -tafeln für das grönländische Inlandeis zu erstellen. Daraus ergibt sich, dass die Schneeoberfläche etwa in $1300 \mathrm{~m}$ Höhe in Nordgrönland und bis zu $2700 \mathrm{~m}$ Höhe in Südgrönland schmelzen dürfte. Der Zuwachs von Wärme in der Arktis, der aus steigenden Jahresmitteln der Lufttemperatur zu ersehen ist, dürfte geringer sein auf dem Inlandeis als bei den am Meeresspiegel angelegten Küstenstationen. Jährliche Akkumulation durch Niederschläge ist zwei- oder dreimal grösser in $2700 \mathrm{~m}$ Höhe an der Westseite des Eises als am Gipfel. Südlich von Breite $66^{\circ} \mathrm{N}$ dürften die Niederschläge etwa doppelt so gross sein an der Ostseite des Gipfels als an der Westseite.

\section{INTRODUCTION}

The Greenland Ice Sheet is the second largest glacier in the world, exceeded in size only by the ice sheet covering the Antarctic Continent. The ice sheet which occupies all of Greenland except a narrow belt of exposed land around the coast, is nearly 1,500 miles $(2,400 \mathrm{~km}$.) long and 200 to 500 miles ( 300 to $800 \mathrm{~km}$.) wide and has an area of about 637,000 square miles $\left(\mathrm{I}, 65_{5}, 000 \mathrm{~km} .{ }^{2}\right)$. Its southern tip extends south of the Arctic Circle to about lat. $6 \mathrm{I}^{\circ} \mathrm{N}$. and its northern limit is about 700 miles $(1,100 \mathrm{~km}$.) from the North Pole.

This report makes use of available meteorological and glaciological data to construct maps showing the distribution of mean annual precipitation and mean annual air temperature on the ice sheet. Some climatological data are available from the ice-sheet area. They are for the most part the product of short-period records from the reports of expeditions and scientific parties that spent a few summer months on the ice sheet and a few parties that wintered in the central area. The U.S. Air Force operated two weather stations on the ice cap in north-west Greenland for several years following their establishment in 1953. These two weather stations are the only locations where meteorological data have been continuously collected on the ice sheet for more than two years.

Other ice sheet stations from which meteorological and glaciological data are available for periods of about I year are:

* Work performed while Mr. Diamond was with U.S. Army Snow, Ice and Permafrost Research Establishment, Corps of Engineers, Wilmette, Illinois, U.S.A. 


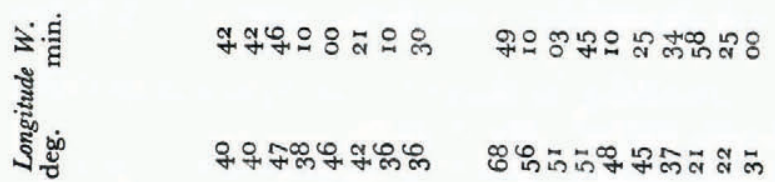

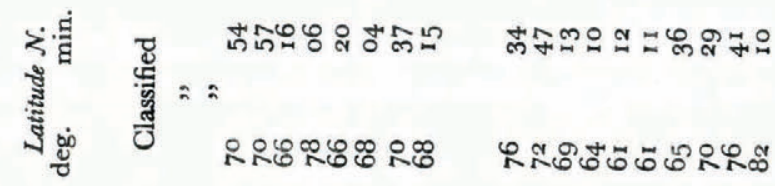

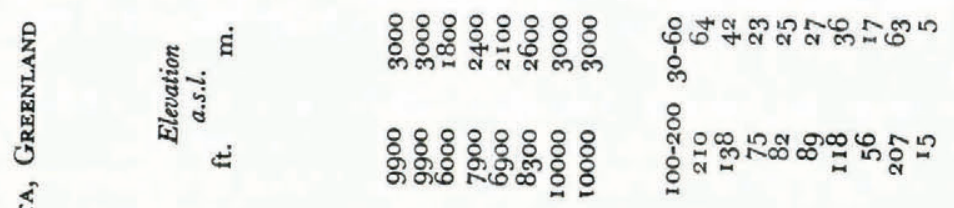

政
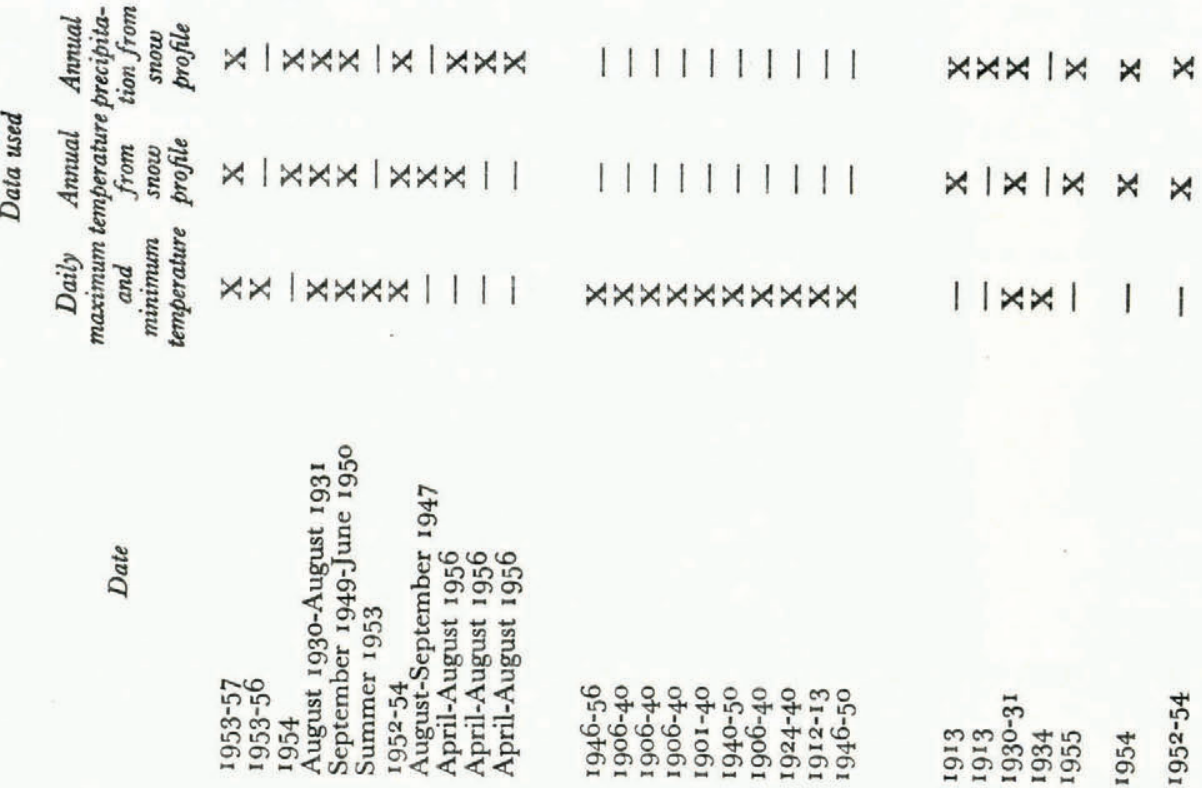

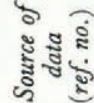

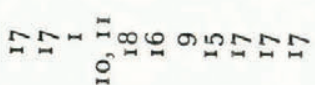

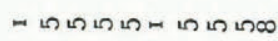

Nogm a
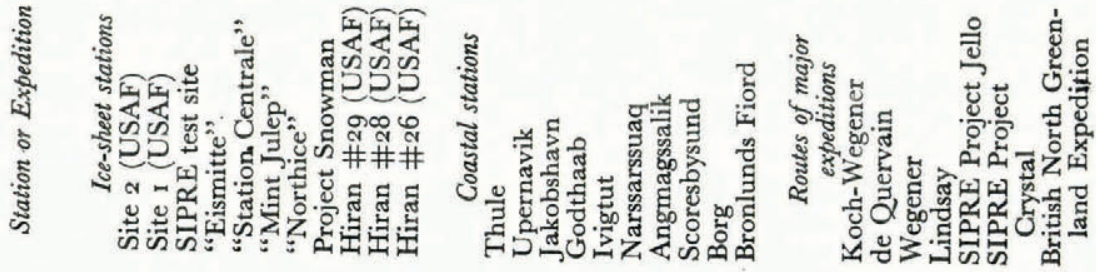
(a) "Eismitte", a station located on the west slope near the crest of the ice sheet in south central Greenland, which was manned for I year during 1930-3 I by members of the Wegener expedition. ${ }^{19}$

(b) "Station Centrale", established in almost the same location as Eismitte and operated during r $949-50$ by Expéditions Polaires Françaises. ${ }^{18}$

(c) "Northice", a station located on the east slope near the crest of the ice sheet in north central Greenland, which was operated during November I952-July I 954 by members of the British North Greenland Expedition.?

The location of stations and routes of major expeditions from which data were obtained are shown in Figure I. Station information used in this report is presented in Table I.

\section{Derivation of Mean Annual Air Temperature Data}

Mean annual air temperatures were computed from the record of daily maximum and minimum air temperature observations made at U.S. Air Force Site 2, "Eismitte", "Station Centrale", and "Northice".

To supplement the air temperature records from these stations, snow profile temperature data collected at eight locations on the ice sheet (see Fig. 2 and Table I) were used. In glacier areas where little or no melting occurs, the amplitude of the annual temperature wave decreases to about $0.5^{\circ} \mathrm{C}$. at $8 \mathrm{~m}$. below the surface, so that the snow temperature at this depth is close to the local mean annual air temperature (B. L. Hansen, personal communication; Koch and Wegener ${ }^{\mathrm{I} 2}$ ). This relationship, which is substantiated by the data presented. in Table II, was used in the preparation of a mean annual air temperature chart for the Greenland Ice Sheet (Fig. 2).

Table II. Comparison of Mean Annual Air Temperatures with Snow Temperatures at 8 m. Below the SURFACE

\begin{tabular}{|c|c|c|c|}
\hline Station & $\begin{array}{c}\text { Mean annual } \\
\text { air temp. } \\
{ }^{\circ} \mathrm{C} \text {. }\end{array}$ & $\begin{array}{c}\text { Snow temp. } 8 \mathrm{~m} . \\
\text { below surface } \\
{ }^{\circ} \mathrm{C} .\end{array}$ & $\begin{array}{l}\text { Year of snow } \\
\text { observations }\end{array}$ \\
\hline Site 2 & $\begin{array}{l}-24 \\
(1054-1056)\end{array}$ & -24 & 1954 \\
\hline "Eismitte" & $\begin{array}{c}\left(1954^{-1950)}\right. \\
-31 \\
(1930-1931)\end{array}$ & -28 & 1931 \\
\hline "Station Centrale" & $\begin{array}{c}-27^{*} \\
(1949-1950)\end{array}$ & -28 & $195^{\circ}$ \\
\hline "Northice" & $\begin{array}{c}-30 \\
\text { (1953-1954) }\end{array}$ & -28 & I953 \\
\hline
\end{tabular}

* Estimated from September-June data. Mean for September-June of $-30^{\circ} \mathrm{C}$. raised to $-27^{\circ} \mathrm{C}$. for September-August to account for higher temperatures during July and August. Mean September-June temperature at "Eismitte" was $-34^{\circ} \mathrm{C}$. and mean September-August temperature was $-31^{\circ} \mathrm{C}$.

The temperatures recorded at coastal stations were used to derive the location of isotherms at higher elevations and approximately the same latitude. Wegener ${ }^{12}$ and de Quervain ${ }^{6}$ found a lapse rate of $0.6^{\circ} \mathrm{C}$. $/ 100 \mathrm{~m}$. applicable on the Greenland Ice Sheet. Orvig ${ }^{14}$ obtained a lapse rate of $0.6^{\circ} \mathrm{C}$./ $100 \mathrm{~m}$. between coastal and glacier stations on Baffin Island. In this study a mean lapse rate of $0.7^{\circ} \mathrm{C}$./ $100 \mathrm{~m}$. was found, computed from the mean annual air temperature at five coastal sites and mean annual air temperature, as estimated from snow profile studies, at five inland ice stations at approximately the same latitude (Table III). This lapse rate was used to compute mean annual air temperatures for ice-sheet areas where no air or snow temperature was available.

The lowest mean annual air temperature in south Greenland is estimated to occur within the area bounded by the $2,500 \mathrm{~m}$. contour and the $-18^{\circ} \mathrm{C}$. isotherm (Fig. 2). Assuming a maximum elevation of $2,700 \mathrm{~m}$. for this area, a mean annual air temperature at sea-level of 


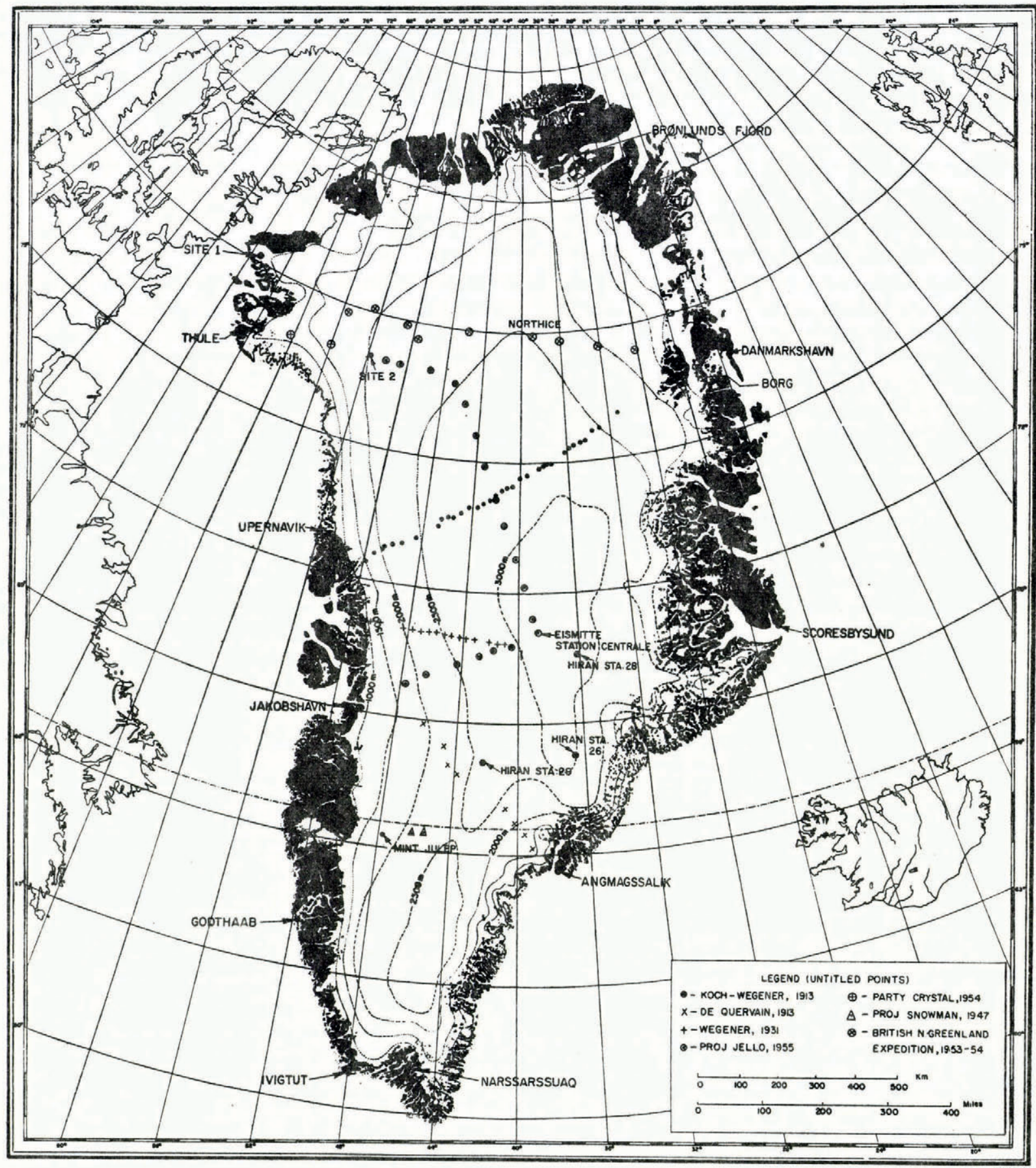

Fig. I. Location of stations and routes of expeditions 
Table III. Computation of Mean Annual Lapse Rate on the Greenland Ice Sheet

\begin{tabular}{|c|c|c|c|c|c|c|c|}
\hline $\begin{array}{l}\text { Sea-level } \\
\text { coastal } \\
\text { station }\end{array}$ & $\begin{array}{l}\text { Latitude } \\
{ }^{\circ} \mathrm{N} .\end{array}$ & $\begin{array}{c}\text { Mean annual } \\
\text { air temperature } \\
{ }^{\circ} \mathrm{C} \text {. }\end{array}$ & $\begin{array}{l}\text { Ice-Sheet } \\
\text { station }\end{array}$ & $\begin{array}{l}\text { Latitude } \\
{ }^{\circ} \mathrm{N} .\end{array}$ & $\begin{array}{c}\text { Elevation } \\
\mathrm{m} .\end{array}$ & $\begin{array}{l}\text { Mean annual } \\
\text { air temperature from } \\
\text { snow profile } \\
{ }^{\circ} \mathrm{C} \text {. }\end{array}$ & $\begin{array}{c}\text { Lapse } \\
\text { rate } \\
{ }^{\circ} \mathrm{C} . / \mathrm{I} \text { oo m. }\end{array}$ \\
\hline $\begin{array}{l}\text { Thule } \\
\text { Thule } \\
\text { Upernavik } \\
\text { akobshavn } \\
\text { akobshavn }\end{array}$ & $\begin{array}{l}76 \\
76 \\
73 \\
69 \\
69\end{array}$ & $\begin{array}{l}-12(1946-56) \\
-12(1946-56) \\
-7(1921-30) \\
-4(1921-30) \\
-3(1931-40)\end{array}$ & $\begin{array}{l}\text { Site } 2 \\
\text { Party Crystal } \\
\text { Koch-Wegener } \\
\text { "Eismitte" } \\
\text { Hiran \#29 }\end{array}$ & $\begin{array}{l}77 \\
77 \\
74 \\
71 \\
68\end{array}$ & $\begin{array}{l}2000 \\
2300 \\
2900 \\
3000 \\
2600\end{array}$ & $\begin{array}{l}-24(1954) \\
-28(1954) \\
-31(1930) \\
-28(1930) \\
-23(1956) \\
\text { Mean }\end{array}$ & $\begin{array}{l}0 \cdot 60 \\
0 \cdot 70 \\
0 \cdot 82 \\
0 \cdot 80 \\
0 \cdot 77 \\
0 \cdot 74\end{array}$ \\
\hline
\end{tabular}

$-2 \cdot 0^{\circ} \mathrm{C}$. (see Fig. 2), and a lapse rate of $0.7^{\circ} \mathrm{C}$. $/ 100 \mathrm{~m}$., the estimated mean annual air temperature at $2,700 \mathrm{~m}$. is $-20.9^{\circ} \mathrm{C}$. In north Greenland between Thule and Site 2, the presence of ice glands ${ }^{2}$ indicates that some melting occurs at elevations of $1,700 \mathrm{~m}$. The estimated mean annual air temperature here is about $-22^{\circ}$ C. (Fig. 2), a degree lower than for the coldest area in south Greenland. It is considered highly probable that normal summer air temperatures at the highest points on the ice sheet in south Greenland are sufficiently high to permit some melting.

Since the mean annual air temperature is a function of both summer and winter temperatures, it is not possible to estimate the amount of melting during the summer months. Such estimates might be made if the frequency of days with air temperatures above freezing was known.

Very few records of air temperatures are available from areas of the ice sheet where melting may occur during the months of June, July, and August. However, daily summer maximum temperatures on the ice sheet can be estimated from daily maximum temperatures at coastal stations, using an appropriate lapse rate. The lapse rate for daily maximum air temperature between Thule and Site 2 was found to be $0.6^{\circ} \mathrm{C}$. $/ 100 \mathrm{~m}$. during the summer (Table IV) which is the same as the mean annual lapse rate between these two stations and less than the average mean annual lapse rate of $0.7^{\circ} \mathrm{C} . / 100 \mathrm{~m}$. for the whole ice sheet.

Table IV. Computation of Summer Lapse Rate on the Greenland Ice Sheet in Northern Greenland

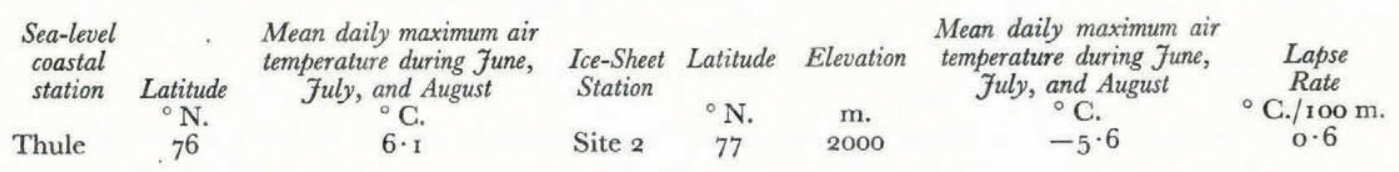

The maximum elevation at which melt will occur is assumed to coincide with the elevation of the $o^{\circ} \mathrm{C}$. air temperature isotherm. However, some melt may possibly occur at air temperatures below $0^{\circ} \mathrm{C}$. due to a positive radiation balance but the amount of such melt would be extremely small. While it has been assumed that melt occurs at air temperatures of $o^{\circ} \mathrm{C}$., a necessary condition for more than just small quantities of melt is that the air temperature remains above $0^{\circ} \mathrm{C}$. for prolonged periods. Since the elevation of this isotherm is related to the daily maximum temperature at sea-level, it may be estimated from sea-level temperatures by the following equation:

Elevation of $o^{\circ} \mathrm{C}$. isotherm $(\mathrm{m})=.\frac{\text { daily maximum temperature at sea-level }\left({ }^{\circ} \mathrm{C} \text {. }\right) \times 100}{0.6}$

The presence of ice masses in the snow at an elevation of $1,300 \mathrm{~m}$. east of Thule ${ }^{2}$ indicates summer melting at this elevation. The air temperature at Thule corresponding to $0^{\circ} \mathrm{C}$. at I,300 m. would be $7 \cdot 8^{\circ} \mathrm{C}$. $\left(46^{\circ} \mathrm{F}\right.$.). During $1946-56$, the three summer months at Thule 


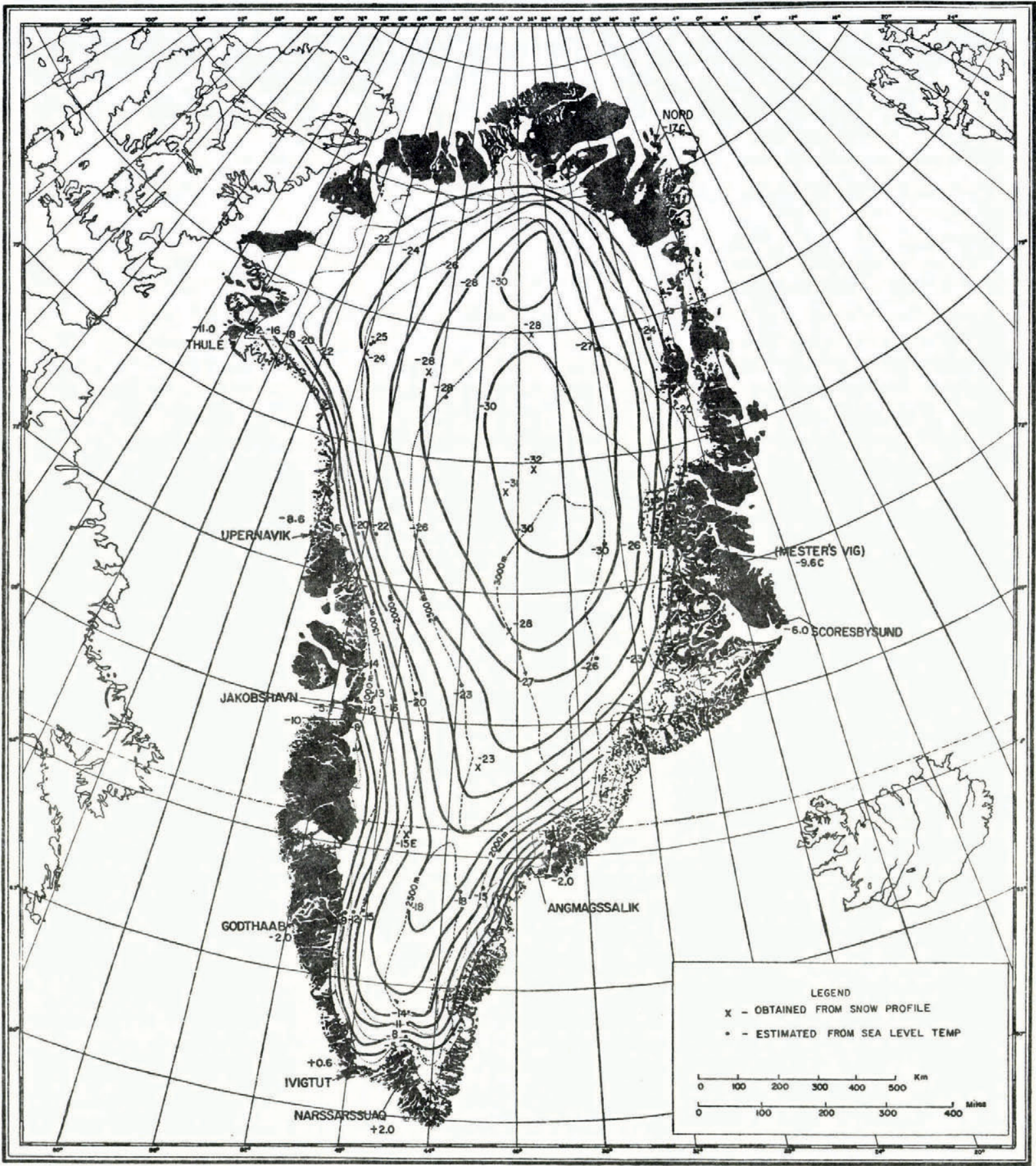

Fig. 2. Mean annual air temperature $\left({ }^{\circ} \mathrm{C}\right.$.) on Greenland Ice Sheet 
averaged 32 days with maximum temperatures equal to or higher than $46^{\circ} \mathrm{F}$., indicating a potentially high incidence of melting at $1,300 \mathrm{~m}$. during the summer.

The presence of ice glands in the snow cover at $1,700 \mathrm{~m}$. indicates some snow melting at this elevation. The air temperature at Thule corresponding to an air temperature of $0^{\circ} \mathrm{C}$. at $1,700 \mathrm{~m}$. is $10^{\circ} \mathrm{C}$. $\left(50^{\circ} \mathrm{F}\right.$.). Daily maximum temperatures at Thule during the three summer months equal or exceed $50^{\circ} \mathrm{F}$. on 14 days. Melting may be assumed to occur at $\mathrm{I}, 700 \mathrm{~m}$. on at least the same number of days.

Assuming that the above relation is applicable to other sections of the ice sheet, the extent of melting in other areas can be estimated from meteorological records reported from adjacent coastal stations. The number of days on the ice sheet with maximum temperatures above freezing are listed in Table VI for latitudes of $61^{\circ} \mathrm{N}, 67^{\circ} \mathrm{N}$. and $74^{\circ} \mathrm{N}$. The data indicate that, south of lat. $67^{\circ} \mathrm{N}$., considerable melt will occur at elevations as high as $2,700 \mathrm{~m}$. Below lat. $67^{\circ} \mathrm{N}$., there are as many days with above freezing temperatures at $2,700 \mathrm{~m}$. as there are at $1,300 \mathrm{~m}$. at lat. $76^{\circ} \mathrm{N}$., where ice masses have been observed in the snow cover.

That melting may occur at elevations above $2,500 \mathrm{~m}$. in south Greenland is substantiated by observations of air temperatures above $0^{\circ} \mathrm{C}$. in the south central portion of the ice sheet. During the British Trans-Greenland Expedition, ${ }^{13}$ crossing the ice sheet near lat. $72^{\circ} \mathrm{N}$. in 1934, temperatures of $+0.5^{\circ} \mathrm{C}$. were encountered at 2,700 m. During the summer $195^{6}$, $0^{\circ}$ C. temperatures were measured at U.S. Air Force Hiran stations south of lat. $70^{\circ} \mathrm{N}$. on the Greenland Ice Sheet between elevations 2,500-2,800 m. Snow pit profiles made at lat. $66^{\circ}$ N., $2,700 \mathrm{~m}$. by Project Snowman, New England Division, Corps of Engineers, ${ }^{\mathrm{I}}{ }^{5}$ indicated considerable melt at these sites (see Fig. I).

The warming trend in the Arctic, as shown by recent increases of mean annual temperature at several west Greenland coastal stations (Table V), appears to have occurred to a

Table V. Comparison of Mean Annual Air Temperatures along the West Coast of Greenland

\begin{tabular}{|c|c|c|c|c|}
\hline \multirow[b]{2}{*}{ Station } & \multicolumn{4}{|c|}{ Mean annual temperature* } \\
\hline & $\begin{array}{l}\text { Latitude } \\
\circ \mathrm{N} .\end{array}$ & $\begin{array}{l}1921-40 \\
\mathrm{C} .\end{array}$ & $\begin{array}{l}\text { IgOI-2O } \\
\text { C. }\end{array}$ & $\begin{array}{c}\text { Temperature change } \\
{ }^{\circ} \mathrm{C} \text {. }\end{array}$ \\
\hline Ivigtut & $6 I$ & $+\mathbf{I} \cdot 5$ & +0.9 & +0.6 \\
\hline Godthaab & 64 & $-0.5 \dagger$ & $-1 \cdot 8$ & $+\mathbf{I} \cdot 3$ \\
\hline Angmagssalik & 65 & $-0 \cdot 4$ & $-2 \cdot 0$ & $+1 \cdot 6$ \\
\hline Jakobshavn & 69 & $-3 \cdot 7$ & $-5 \cdot 5$ & $+1 \cdot 8$ \\
\hline Upernavik & 73 & $-5 \cdot 2 \dagger$ & $-8 \cdot 3$ & $+3 \cdot 1$ \\
\hline
\end{tabular}

lesser extent on the ice sheet. At Jakobshavn the I92I-40 mean annual air temperature is $\mathrm{I} \cdot 8^{\circ} \mathrm{C}$. warmer than for the 20 years prior to 1920 . At about the same latitude on the ice sheet, the snow temperature at a depth of $10 \mathrm{~m}$. was $-27.4^{\circ} \mathrm{C}$. at "Station Centrale" in August $195^{\circ}$ and $-28 \cdot 6^{\circ} \mathrm{C}$. in August I931 at "Eismitte", or I $\cdot 2^{\circ} \mathrm{C}$. warmer in $195^{\circ}$ than in 1931 (Heuberger ${ }^{10}$; Wegener ${ }^{19}$ ).

Table Vi. Number of Days on the Greenland Ice Sheet, during June, July, and August, with Maximum Air Temperature Equal to or Greater than $0^{\circ}$ C. Estimated from Sea-level Temperatures

Elevation m.

$\begin{array}{cccccccrrr}\begin{array}{c}\text { Latitude } \\ \circ\end{array} & 500 & 1000 & 1300 & 1500 & 1700 & 2000 & 2500 & 2700 & 3000 \\ 76 & 73 & 51 & 32^{*} & 22 & 14 \dagger & 5 & 0 & 0 & 0 \\ 76 & 91 & 91 & 89 & 86 & 81 & 66 & 41 & 34 & 16 \\ 61 & 92 & 92 & 91 & 90 & 86 & 69 & 41 & 33 & 15\end{array}$

* Presence of ice masses indicates melting at this elevation and latitude.

$\dagger$ Presence of ice glands indicates some meting at this elevation and latitude. 


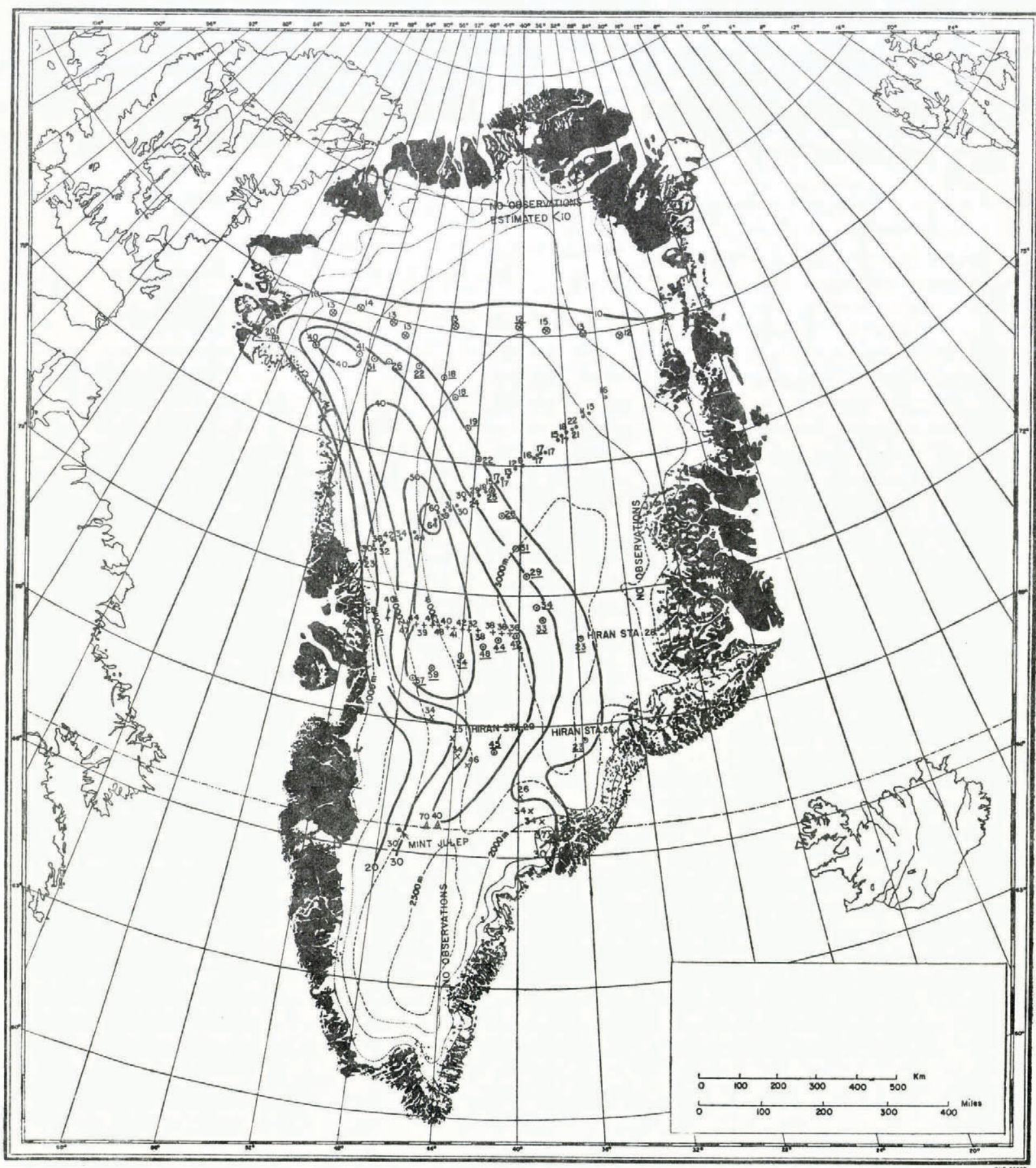

Fig. 3. Mean annual accumulation on Greenland Ice Sheet, in centimetres of water equivalent. The station symbols have the same significance as in Figur: 1 . Underlined figures, such as 45 , are means of four or more years. Figures which are not underlined are one-year measurements 
The lesser rate of warming on the ice sheet, if true, may be due to the great heat-sink capacity of the perpetual snow cover, which has a maximum surface temperature of $0^{\circ} \mathrm{C}$. and therefore has a conservative effect upon changes in air temperatures. Air temperatures in the coastal area, which is snow-free during the summer, are not subject to such a conservative influence and probably reflect the warming trend more quickly than the ice-sheet stations.

\section{Annual Accumulation}

Snow profile studies made at "Eismitte" have shown II that there is a difference in density between summer and winter snows at those elevations on the Greenland Ice Sheet where little or no melting occurs. This difference in density permits dating of a number of annual layers, from which an estimation of mean annual accumulation can be made. Prior to 1931, records for only a single year's accumulation were available. These were derived from measurements, made by scientific parties, of the thickness and density of snow that had been deposited during that year.

The values of mean annual accumulation as estimated from snow profile studies and the yearly accumulation derived from records of various scientific parties have been used to prepare a mean annual accumulation map for the Greenland Ice Sheet (Fig. 3).

The annual accumulation estimated from snow profile studies may not represent an accurate measurement of annual snowfall since drifting may increase or decrease the apparent accumulation. The gain or loss in accumulation due to drifting is not known, but the almost constant katabatic wind flowing down the ice sheet probably moves some of the cold dry snow from higher elevations to the melt zone at lower elevations, where higher temperatures may cause the snow to become more cohesive, reducing its ability to drift. As indicated in Figure 3, the area of maximum annual accumulation does not coincide with the crest of the ice sheet.

Since the present maximum annual accumulation is not at the crest, it would appear that the present shape of the ice sheet might be subject to change unless there are compensations for the greater accumulation at the lower elevations. The only known compensating factor is the outward movement of ice from the bottom of the ice sheet. The high rate of iceberg formation along the west coast of Greenland adjacent to the area of maximum accumulation, shown in Figure 3, suggests a strong outflow of ice in this area.

The accumulation measurements made by the British North Greenland Expedition during its traverse of the ice sheet 4 indicates an almost constant accumulation of 12-14 cm. of water equivalent along lat. $78^{\circ} \mathrm{N}$. If these values are correct, then the ice sheet area north of lat. $7^{\circ} \mathrm{N}$. apparently receives less than $12 \mathrm{~cm}$. water equivalent of snow or about $35 \mathrm{~cm}$. of new snow annually.

The only accumulation data for the east slope of the ice sheet is the series of measurements obtained during the Koch-Wegener ice-sheet crossing, Koch-Wegener. ${ }^{12}$ Long-term records show that Angmagssalik, on the east coast at lat. $65.5^{\circ} \mathrm{N}$., receives about $90 \mathrm{~cm}$. of precipitation annually, while Godthaab, on the west coast at lat. $64^{\circ} \mathrm{N}$., receives about $60 \mathrm{~cm}$. annually. This indicates that, south of lat. $66^{\circ} \mathrm{N}$., annual snow accumulation may be greater on the east slope than on the west slope of the ice sheet. 5 This difference in precipitation may be attributed to the path of the main storm track, which lies between south Greenland and Iceland. North of lat. $66^{\circ} \mathrm{N}$. there are no stations on the east coast with precipitation records which may be compared with records from west-coast stations. Consequently, the northward extent of the apparent greater accumulation on the east coast cannot be determined.

The snow profile studies 7 at Site 2 indicate a decreasing trend in annual accumulation at this site between 1932 and 1954 . The five-year mean from I930-34 was $49 \mathrm{~cm}$. of water equivalent while the five-year mean from $1950-54$ was $39 \mathrm{~cm}$. of water equivalent. This is contrary to the results obtained at "Northice", 250 miles ( $400 \mathrm{~km}$.) to the east on the east slope, where an increase in annual accumulation from $7 \mathrm{~cm}$. of water equivalent in 1940 to I I cm. of water equivalent in $195^{\circ}$ has been reported. ${ }^{4}$ 
Because of the effect of drifting upon the measurement of accumulation, it is not possible to determine whether this difference in accumulation trends represents a difference in precipitation trends or simply a change in drift patterns. If the drift patterns have not changed, the difference in precipitation trends indicates a wide variation in climatic conditions over an east-west distance of about 250 miles ( $400 \mathrm{~km}$.) in north central Greenland.

MS. received 25 August 1959

\section{REFERENGES}

1. Bader, H., and others. Excavations and installations at SIPRE test site, Site 2, Greenland, by H. Bader, R. W. Waterhouse, J. K. Landauer, B. L. Hansen, J. A. Bender and T. R. Butkovich. U.S. Snow, Ice and Permafrost Research Establishment. Report 20, 1955.

2. Benson, C. S. Physical investigations on the firn of northwest Greenland. U.S. Snow, Ice and Permafrost Research Establishment. Research Report 26. [In preparation, 1958.]

3. Benson, C. S. Scientific work of Party Crystal 1954. U.S. Snow, Ice and Permafrost Research Establishment. Report 24, $\mathrm{r} 955$.

4. Bull, C. Personal communication to SIPRE, I957.

5. Clayton, H. H., comp. World weather records. Smithsonian Miscellaneous Collections, Vol. 79, r927; Vol. 90, I934; Vol. ro5, 1947.

6. Quervain, A. de. Die West-Ost-Durchquerung des Indlandeises. Ergebnisse der Schweizerischen Naturforschenden Gesellschaft, Denkschriften, Bd. 53, 1920, p. I-151 (text in German). [Also in Meddelelser om Gronland, Bd. 59, 1925 (text in French).]

7. Diamond, M. Precipitation trends in Greenland during the past 30 years. U.S. Snow, Ice and Permafrost Research Establishment. Research Report 22, 1956.

8. Fristrup, B. Physical geography of Peary Land. I. Meddelelser om Gronland, Bd. I27, Nr. 4, 1952.

9. Hamilton, R. A., and others. British North Greenland Expedition 1952-4: scientific results. [By] R. A. Hamilton and others. Geographical fournal, Vol. 122, Pt. 2, 1956, p. 203-40.

ro. Heuberger, J.-C. Glaciologie. Groenland. Vol. I: forages sur l'inlandsis. Paris, Hermann, I954. (Actualités scientifiques et industrielles, 12 r 4. Expéditions Polaires Françaises [travaux], 5.)

11. Sorge, E. Glaziologische Untersuchungen in Eismitte. (In Brockamp, B., and others. Glaziologie. Leipzig, F. A. Brockhaus, r 935 , p. 62-270. (Wissenschaftliche Ergebnisse der deutschen Grönland-Expedition Alfred Wegener 1929 und $1930 / 1931$, Bd. 3.))

12. Koch, J. P., and Wegener, A. Wissenschaftliche Ergebnisse der dänischen Expedition nach Dronning LouisesLand und quer über das Inlandeis von Nordgrönland, 1912-13. Meddelelser om Grenland, Bd. 75, 1930.

13. Lindsay, M. Sledge: the British Trans-Greenland Expedition, 1934. London, Cassel and Co., Ltd., I935.

14. Orvig, S. Glacial-meteorological observations on ice caps in Baffin Island. Geografiska Annaler, Årg. 36, Ht. $3-4$, r954, p. 197 .

15. Investigation of construction and maintenance of airdromes on ice. (1946-47) Report of investigations. Boston, Mass., Arctic Construction and Frost Effects Laboratory, New England Division, Corps of Engineers, U.S. Army,
I 947 . (Report TR8.)

16. Schuster, R. L. Project Mint Julep. Part III. Snow studies. U.S. Snow, Ice and Permafrost Research Establishment. Report 19, 1954.

17. U.S. Weather Bureau, National Weather Records Center, Asheville, North Carolina.

18. [Expéditions Polaires Françaises.] Les observations météorologiques de la Station Française du Groenland. Conditions atmospheriques en surface dú 5 septembre 1949 au 20 juin 1950. Fasc. I. Relevés quotidiens. Paris, Météorologie Nationale et Expéditions Polaires Françaises, r954.

r9. Wegener, K., and others. Wissenschaftliche Ergebnisse der deutschen Grönland-Expedition Alfred Wegener rg29 und 1930/1931. Leipzig, F. A. Brockhaus, 1935. 7 vols. 